\title{
Effect of Obesity on B-Type Natriuretic Peptide Levels in Patients With Pulmonary Arterial Hypertension
}

\author{
Omar Batal, MD ${ }^{\mathrm{a}}$, Michael Faulx, MD ${ }^{\mathrm{b}}$, Richard A. Krasuski, MD ${ }^{\mathrm{b}}$, Omar F. Khatib, MD ${ }^{\mathrm{a}}$, \\ Jeff P. Hammel, MS , Ayman A. Hussein, MD ${ }^{\mathrm{a}}$, Omar A. Minai, MD ${ }^{\mathrm{c}}$, and Raed A. Dweik, MD ${ }^{\mathrm{c}, *}$
}

\begin{abstract}
Brain natriuretic peptide (BNP) levels are lower in obese patients with left ventricular failure than in their comparably ill, leaner counterparts. The effect of obesity on BNP in patients with pulmonary arterial hypertension (PAH) is unknown. We reviewed our prospective PAH registry data collected from November 2001 to December 2007 for patients undergoing right heart catheterization who met the criteria for $\mathrm{PAH}$ and had the BNP level and body mass index determined at baseline. The median BNP level for the lean, overweight, and obese patients was $285 \mathrm{pg} / \mathrm{ml}$ (interquartile range 131 to 548), $315 \mathrm{pg} / \mathrm{ml}$ (interquartile range 88 to 531), and $117 \mathrm{pg} / \mathrm{ml}$ (interquartile range 58 to 270), respectively $(\mathrm{p}=0.029)$. A greater body mass index was associated with a lower BNP level, adjusted for age, gender, New York Heart Association functional class, hypertension, coronary artery disease, and mean right atrial and pulmonary arterial pressures $(\mathrm{p}<0.001)$. No statistically significant differences were found among the groups in age, race, medical co-morbidities, underlying etiology of $\mathrm{PAH}$, use of vasoactive medications, New York Heart Association functional class, echocardiographic parameters, or pulmonary function. Obese patients had greater right atrial and pulmonary artery pressures. Increased BNP was associated with worse survival in the lean and overweight patients only. In conclusion, the BNP levels are attenuated in obese patients with PAH despite similar or worse hemodynamics or functional class compared to lean or overweight patients and should therefore be interpreted with caution. (C) 2012 Elsevier Inc. All rights reserved. (Am J Cardiol 2012;110:909-914)
\end{abstract}

Increased plasma brain natriuretic peptide (BNP) levels are associated with greater hemodynamic impairment, poorer functional capacity, and reduced survival in patients with idiopathic pulmonary arterial hypertension $(\mathrm{PAH}){ }^{1,2}$ BNP correlates with the degree of right ventricular overload and dysfunction in patients with $\mathrm{PAH}^{3}$ Thus, BNP has assumed an increasingly important clinical role in the evaluation of patients with PAH. ${ }^{4-6}$ Compared to leaner subjects, BNP levels are attenuated in obese subjects with left ventricular dysfunction, even in the presence of heart failure symptoms and increased left ventricular filling pressure. ${ }^{7-9}$ Nonetheless, in patients with left-sided heart failure, BNP remains a clinically useful predictor of exercise intolerance, hemodynamic impairment, and mortality at all levels of body mass index (BMI), although lower cutpoints appear necessary for patients with an elevated BMI. ${ }^{7,10}$ Whether a similar interaction between BNP and obesity occurs in subjects with PAH is not known. The present study investigated the relation between BNP and BMI in patients with PAH.

Departments of ${ }^{\mathrm{a}}$ General Internal Medicine, ${ }^{\mathrm{b}}$ Cardiovascular Medicine, and ${ }^{\mathrm{c} P u l m o n a r y, ~ A l l e r g y, ~ a n d ~ C r i t i c a l ~ C a r e, ~ C l e v e l a n d ~ C l i n i c, ~ C l e v e l a n d, ~}$ Ohio. Manuscript received February 27, 2012; revised manuscript received and accepted May 8, 2012.

*Corresponding author: Tel: 216 445-5763; fax: (216) 445-8160.

E-mail address: dweikr@ccf.org (R.A. Dweik).

\section{Methods}

We reviewed a large, single-center, prospectively collected database of consecutive patients undergoing rightsided heart catheterization for evaluation of PAH from November 2001 to December 2007. Patients $<18$ years old, those with a diagnosis of heart failure, and those requiring dialysis were excluded. Of the 530 patients undergoing right-sided heart catheterization, 380 did not have PAH, 42 patients not have the baseline BNP measured, and 4 did not have the baseline BMI determined and were excluded, leaving a study population of 104 patients with World Health Organization category I PAH. Heart failure and PAH were defined according to the established guidelines. ${ }^{11,12}$

We reviewed our institutional review board-approved registry for demographics, medical history, PAH classification, ${ }^{12}$ pulmonary vasodilator medication use, New York Heart Association (NYHA) functional class, 6-minute walk distance, serum BNP (using the Biosite assay), blood urea nitrogen, serum creatinine, pulmonary function test data, transthoracic echocardiographic data, hemodynamic data, and Social Security Death Index data. Coronary artery disease, hyperlipidemia, and hypertension were defined according to established guidelines. ${ }^{13}$ The included data were within 2 months of the diagnostic right-sided heart catheterization. Data were missing for the following variables: echocardiography ( $2 \%$ missing), creatinine ( $0.9 \%$ missing), NYHA functional class ( $0.9 \%$ missing), 6-minute walk test (16\% missing). All patients had the hemodynamic data 
Table 1

Patient characteristics by body mass index (BMI) class

\begin{tabular}{|c|c|c|c|c|}
\hline \multirow[t]{2}{*}{ Variable } & \multicolumn{4}{|c|}{$\operatorname{BMI}\left(\mathrm{kg} / \mathrm{m}^{2}\right)$} \\
\hline & $\begin{array}{c}<25 \\
(\mathrm{n}=26)\end{array}$ & $\begin{array}{c}25-30 \\
(\mathrm{n}=38)\end{array}$ & $\begin{array}{c}>30 \\
(n=40)\end{array}$ & p Value \\
\hline Age (years) & $51 \pm 3$ & $56 \pm 2$ & $55 \pm 2$ & 0.44 \\
\hline Women & $85 \%$ & $60 \%$ & $82 \%$ & 0.038 \\
\hline Coronary artery disease & $8 \%$ & $3 \%$ & $10 \%$ & 0.47 \\
\hline Diabetes mellitus & $4 \%$ & $13 \%$ & $18 \%$ & 0.29 \\
\hline Hyperlipidemia & $8 \%$ & $18 \%$ & $10 \%$ & 0.42 \\
\hline Hypertension & $35 \%$ & $45 \%$ & $43 \%$ & 0.71 \\
\hline Chronic kidney disease & $8 \%$ & $10 \%$ & 0 & 0.10 \\
\hline Smoker & $50 \%$ & $55 \%$ & $38 \%$ & 0.27 \\
\hline \multicolumn{5}{|l|}{ Medication } \\
\hline Prostanoids & $50 \%$ & $40 \%$ & $60 \%$ & 0.19 \\
\hline Endothelin receptor blockers & $27 \%$ & $28.9 \%$ & $15 \%$ & 0.30 \\
\hline Phosphodiesterase V inhibitors & $19 \%$ & $24 \%$ & $18 \%$ & 0.79 \\
\hline No vasodilators & $4 \%$ & $16 \%$ & $12 \%$ & 0.34 \\
\hline Combination & $4 \%$ & $8 \%$ & $3 \%$ & 0.53 \\
\hline New York Heart Association functional class & $3.1 \pm 0.1$ & $3.1 \pm 0.1$ & $3.2 \pm 0.1$ & 0.83 \\
\hline Six-minute walk distance $(\mathrm{m})$ & $312 \pm 28$ & $303 \pm 22$ & $272 \pm 17$ & 0.40 \\
\hline \multicolumn{5}{|l|}{ Hemodynamics } \\
\hline Mean right atrial pressure (mm $\mathrm{Hg})$ & $9 \pm 1$ & $9 \pm 1$ & $12 \pm 1$ & 0.05 \\
\hline Mean pulmonary artery pressure (mm Hg) & $51 \pm 3$ & $44 \pm 2$ & $52 \pm 2$ & 0.017 \\
\hline Pulmonary vascular resistance (Wood units) & $12 \pm 1$ & $10 \pm 1$ & $10 \pm 1$ & 0.5 \\
\hline Pulmonary capillary wedge pressure (mm $\mathrm{Hg}$ ) & $8.7 \pm 0.8$ & $9.5 \pm 0.5$ & $10 \pm 0.6$ & 0.13 \\
\hline Cardiac index $\left(\mathrm{L} / \mathrm{min} / \mathrm{m}^{2}\right)$ & $2.3 \pm 0.1$ & $2.4 \pm 0.1$ & $2.5 \pm 0.2$ & 0.76 \\
\hline Ejection fraction $(\%)$ & $55 \pm 1$ & $57 \pm 1$ & $56 \pm 1$ & 0.35 \\
\hline Right ventricular systolic pressure (mm Hg) & $86 \pm 6$ & $78 \pm 4$ & $82 \pm 3$ & 0.30 \\
\hline Pericardial effusion & $29 \%$ & $26 \%$ & $18 \%$ & 0.57 \\
\hline Forced expiratory lung volume in $1 \mathrm{~s}$ (L) & $2.1 \pm 0.1$ & $2.2 \pm 0.1$ & $2.0 \pm 0.1$ & 0.76 \\
\hline Carbon monoxide diffusion capacity & $12 \pm 2$ & $15 \pm 2$ & $15 \pm 2$ & 0.62 \\
\hline Blood urea nitrogen (mg/dl) & $22 \pm 2$ & $20 \pm 2$ & $19 \pm 1$ & 0.17 \\
\hline Creatinine $(\mathrm{mg} / \mathrm{dl})$ & $1.0 \pm 0.2$ & $1.0 \pm 0.1$ & $0.9 \pm 0.1$ & 0.82 \\
\hline
\end{tabular}

measured; however, $14 \%$ had $\geq 1$ variable obtained using right-sided heart catheterization missing.

Patients were grouped according to their BMI as lean $\left(<25.0 \mathrm{~kg} / \mathrm{m}^{2}\right)$, overweight $\left(25.0\right.$ to $\left.29.9 \mathrm{~kg} / \mathrm{m}^{2}\right)$, or obese $\left(\geq 30.0 \mathrm{~kg} / \mathrm{m}^{2}\right) .{ }^{14}$ The quantitative variables are summarized within the BMI group as the mean $\pm \mathrm{SD}$, except for the BNP levels, for which the median and interquartile range are reported. The quantitative variables were compared using the Kruskal-Wallis test and the categorical variables using chi-square tests. Within the BMI groups, comparisons with respect to dichotomized patient characteristics were performed with Wilcoxon rank sum tests. Multivariate linear regression analysis of continuous logtransformed BNP versus obesity and covariates reflective of disease severity was performed. Cox regression analysis using backward stepwise elimination of variables with Wald $\mathrm{p}>0.10$ as a removal criterion was used to determine the relation of BNP in its log-transformed form to survival. Receiver operating characteristic curves were used to assess the associations between BNP and 2-year survival, with the optimal BNP cutoff values estimated within each BMI group. These cutoffs were then applied to an analysis of overall survival using Kaplan-Meier curves and log-rank tests for comparison. A Cox regression model of survival with respect to $\log _{2} \mathrm{BNP}$, BMI, and their interaction was used to evaluate the strength of the relation between BNP and survival for the different BMI values.

Survival was estimated from the date of right heart catheterization until cardiopulmonary death or until September 2009 using the patient medical records, pulmonary hypertension database, and the Social Security Death Index. None of the 104 patients included in the present study received a lung or a heart-lung transplant during the study period.

\section{Results}

The mean age of the study population at the baseline diagnostic right heart catheterization was $51 \pm 3$ years; $85 \%$ were women, $85 \%$ were European American, and $14 \%$ were African American. The etiology of PAH was idiopathic in $48 \%$, connective tissue disease in $27 \%$, portal hypertension in $13 \%$, congenital heart disease in $10 \%$, human immunodeficiency virus related in 1 , and drug related in 1 . The medications used included prostanoids (50\%), endothelin receptor blockers (23\%), phosphodiesterase V inhibitors (20\%), $11 \%$ were not taking pulmonary vasoactive medications, and $5 \%$ were receiving combination therapy. The patient characteristics according to the BMI groups are listed in Table 1. No statistically significant differences were found between groups in terms of age, race, medical co-morbidities, 


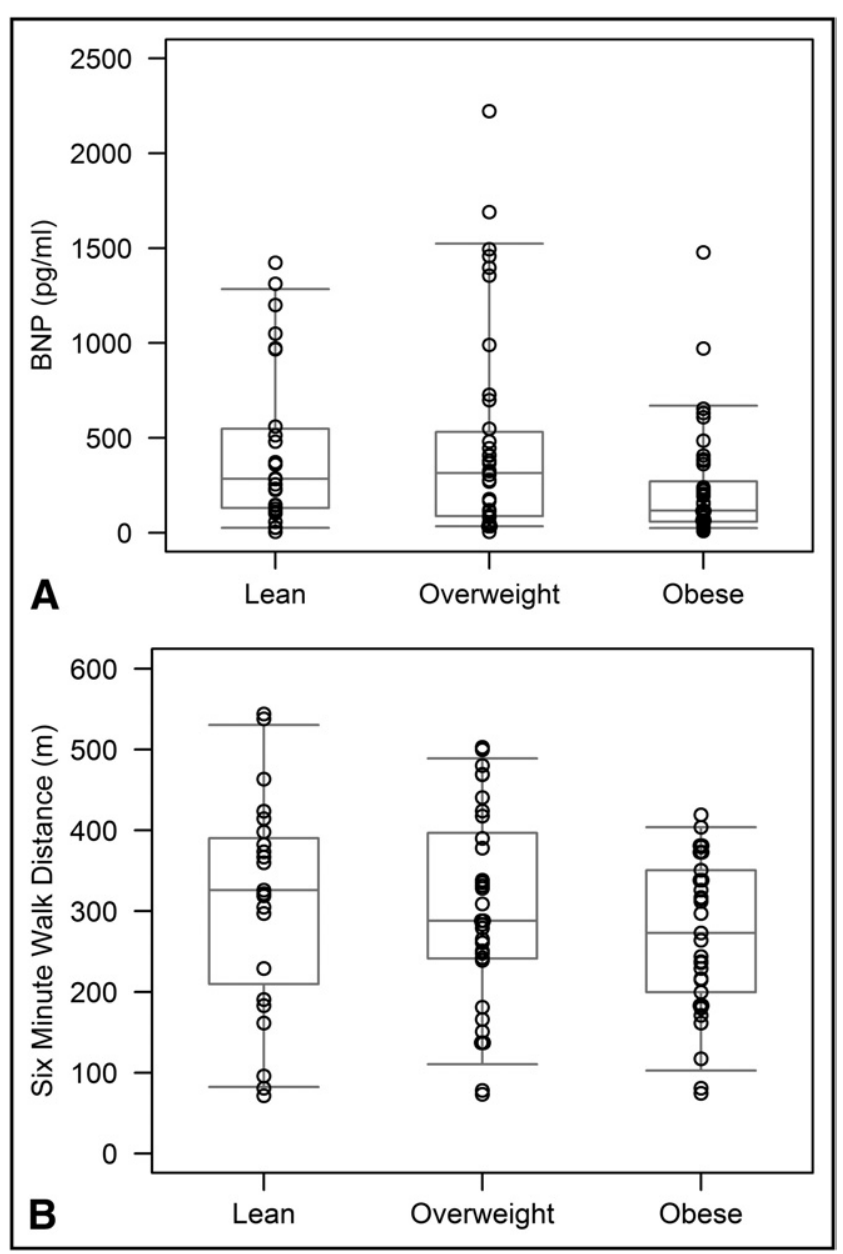

Figure 1. Relation of BNP and 6-minute walk distance to BMI category. (A) Obese patients had a significantly lower BNP value compared to that in the nonobese patients. $(B)$ Although the BNP was lower in obese patients, their functional status as indicated by the 6-minute walk distance was similar.

underlying PAH etiology, use of vasoactive medications, NYHA functional class, echocardiographic parameters studied, or pulmonary function. Obese patients had greater right atrial and mean pulmonary artery pressures.

The plasma BNP was significantly lower in obese patients with PAH compared to that in the overweight or lean patients. The median value for lean, overweight, and obese patients was $285 \mathrm{pg} / \mathrm{ml}$ (interquartile range 131 to 548 ), $315 \mathrm{pg} / \mathrm{ml}$ (interquartile range 88 to 531 ), 117 $\mathrm{pg} / \mathrm{ml}$ (interquartile range 58 to 270 ), respectively $(\mathrm{p}=0.029)$. This was true despite a 6-minute walk distance that was not significantly different among the BMI categories $(p=0.40$; Figure 1$)$. The degree of BNP attenuation among obese subjects was more pronounced in patients aged $\geq 55$ years $(\mathrm{p}<0.001)$ and in women $(\mathrm{p}=0.015$; Figure 2).

Univariate analysis of log-transformed BNP versus BMI was performed and demonstrated that a greater BMI was associated with a lower BNP $(\mathrm{p}=0.011)$. This association was maintained with covariate adjustment for age, gender, NYHA class, hypertension, coronary artery disease, and

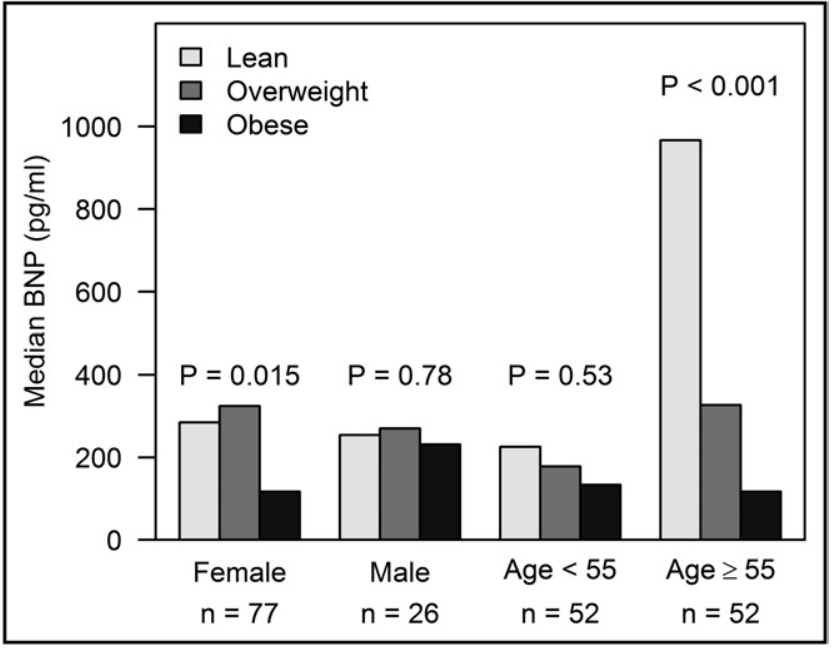

Figure 2. Relation of BNP to gender and age as a function of BMI category.

mean right atrial and pulmonary arterial pressures $(\mathrm{p}<0.001)$.

The patients were followed up for a mean of $3.0 \pm 0.2$ years. During follow-up, 49 patients died: 25 by 1 year and 32 by 2 years. The mean survival rate was not significantly different statistically among the BMI groups $(\log$-rank $\mathrm{p}=$ 0.10 ), with a 2-year survival rate of $77 \%$ for lean patients, $66 \%$ for overweight patients, and $68 \%$ for obese patients. In the study population, BNP was significantly associated with survival, independent of age, BMI, creatinine, and presence of a pericardial effusion on transthoracic echocardiography $(\mathrm{p}=0.01)$. Receiver operating characteristic analysis was performed in each BMI group and revealed an optimal cutoff of $361 \mathrm{pg} / \mathrm{ml}$ for lean patients, $406 \mathrm{pg} / \mathrm{ml}$ for overweight patients, and $50 \mathrm{pg} / \mathrm{ml}$ for obese patients (Figure 3). However, in obese patients, the area under the curve was only 0.55 , suggesting that the BNP level might not be a useful prognostic indicator in obese patients with PAH. These values were then used to construct the Kaplan-Meier curves (Figure 4). The strength of the association of BNP and survival gradually weakened as the BMI increased, and, in patients with a BMI of $\geq 35 \mathrm{~kg} / \mathrm{m}^{2}$, this relation was lost (Figure 5).

\section{Discussion}

An increased serum BNP level is thought to reflect poorer functional capacity, greater hemodynamic impairment and reduced survival in subjects with PAH. ${ }^{1,2}$ In our study, obese patients with PAH had greater pulmonary artery and mean right atrial pressures and similar functional status (NYHA class and 6-minute walk distance) compared to their leaner counterparts but had lower serum BNP levels. Although greater BNP levels have been shown to predict reduced survival in patients with $\mathrm{PAH},{ }^{1}$ we found that BNP was not a good predictor of survival in obese patients with PAH.

Serum BNP levels have been shown to be significantly lower in obese patients in the absence or presence of heart failure. ${ }^{10,15,16}$ In patients with left-sided heart fail- 


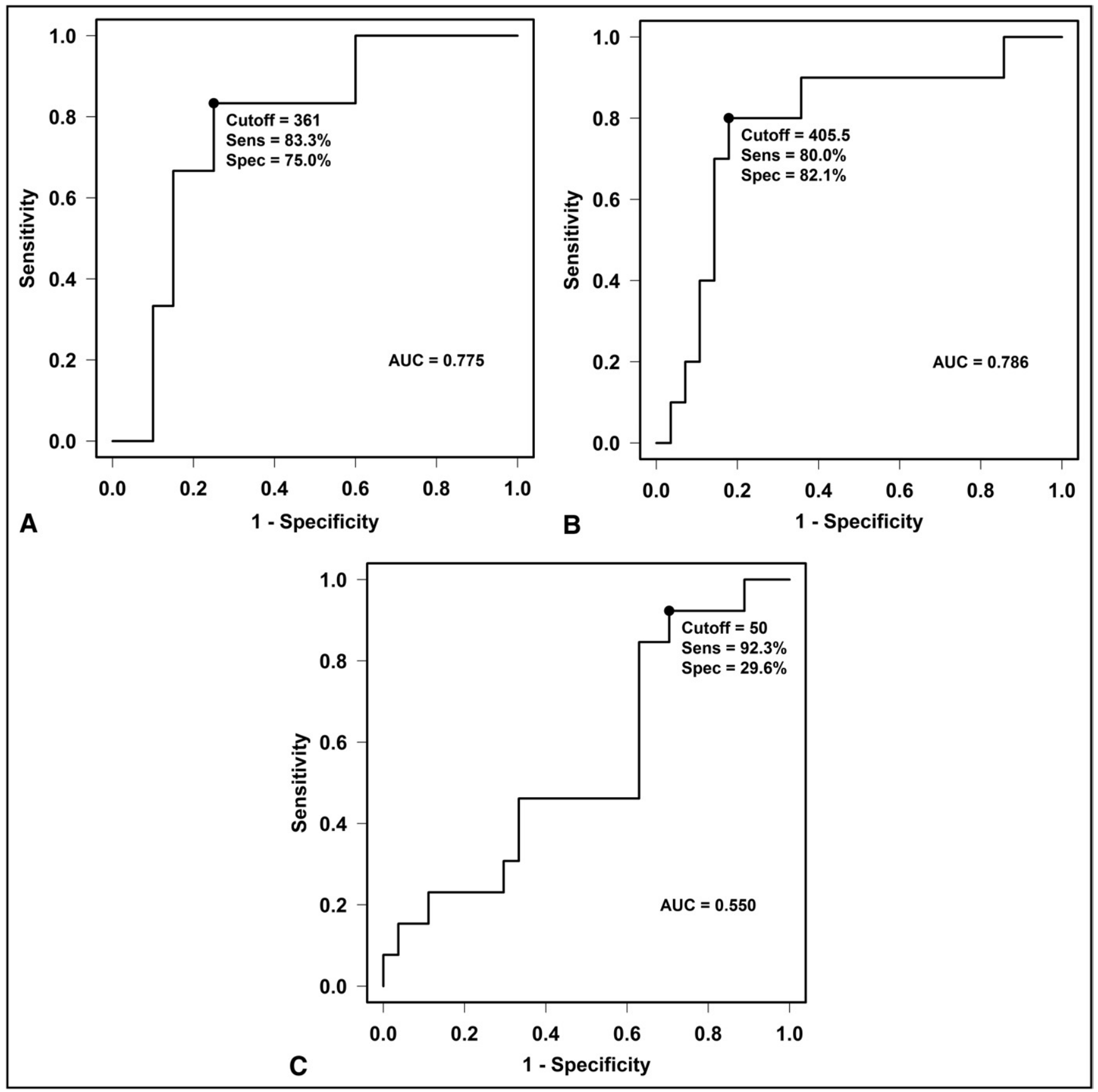

Figure 3. Receiver operating curves for BNP as a function of BMI category: $(A)$ lean, $(B)$ overweight, and $(C)$ obese.

ure, lower circulating levels of BNP have been reported in obese subjects, despite similar heart failure severity, compared to leaner subjects. ${ }^{8,10,17}$ Furthermore, the BNP levels have been shown to predict mortality in patients with heart failure in all BMI categories, although lower cutoffs have been suggested for patients with an elevated BMI. ${ }^{10}$ In our study, we found a similar relation of decreasing BNP levels with obesity in patients with PAH that remained statistically significant on multivariate analysis. Our results have confirmed previous reports of the prognostic significance of BNP in patients with PAH. ${ }^{1,2}$ However, our study also showed that BNP does not appear to be a robust prognostic marker in those with $\mathrm{PAH}$ with a high BMI and that the relation between BNP and survival is statistically significant only in patients with a BMI $<35 \mathrm{~kg} / \mathrm{m}^{2}$.

The cause of BNP attenuation in obese subjects is uncertain. Increased clearance could certainly play a role because removal of the BNP molecule is facilitated by the natriuretic peptide $\mathrm{C}$ receptor found in abundance on adipose cells. ${ }^{16,18,19}$ Alternatively, it is possible that decreased BNP production might be reduced in the setting of obesity. This was suggested by the observation that the levels of $\mathrm{N}$-terminal pro-BNP also tend to be lower in obese subjects. $\mathrm{N}$-terminal pro-BNP is not cleared by the natriuretic peptide $\mathrm{C}$ receptor and serum levels of this pro-molecule correlate with the lean body mass rather than the BMI. ${ }^{20}$ Both BNP 


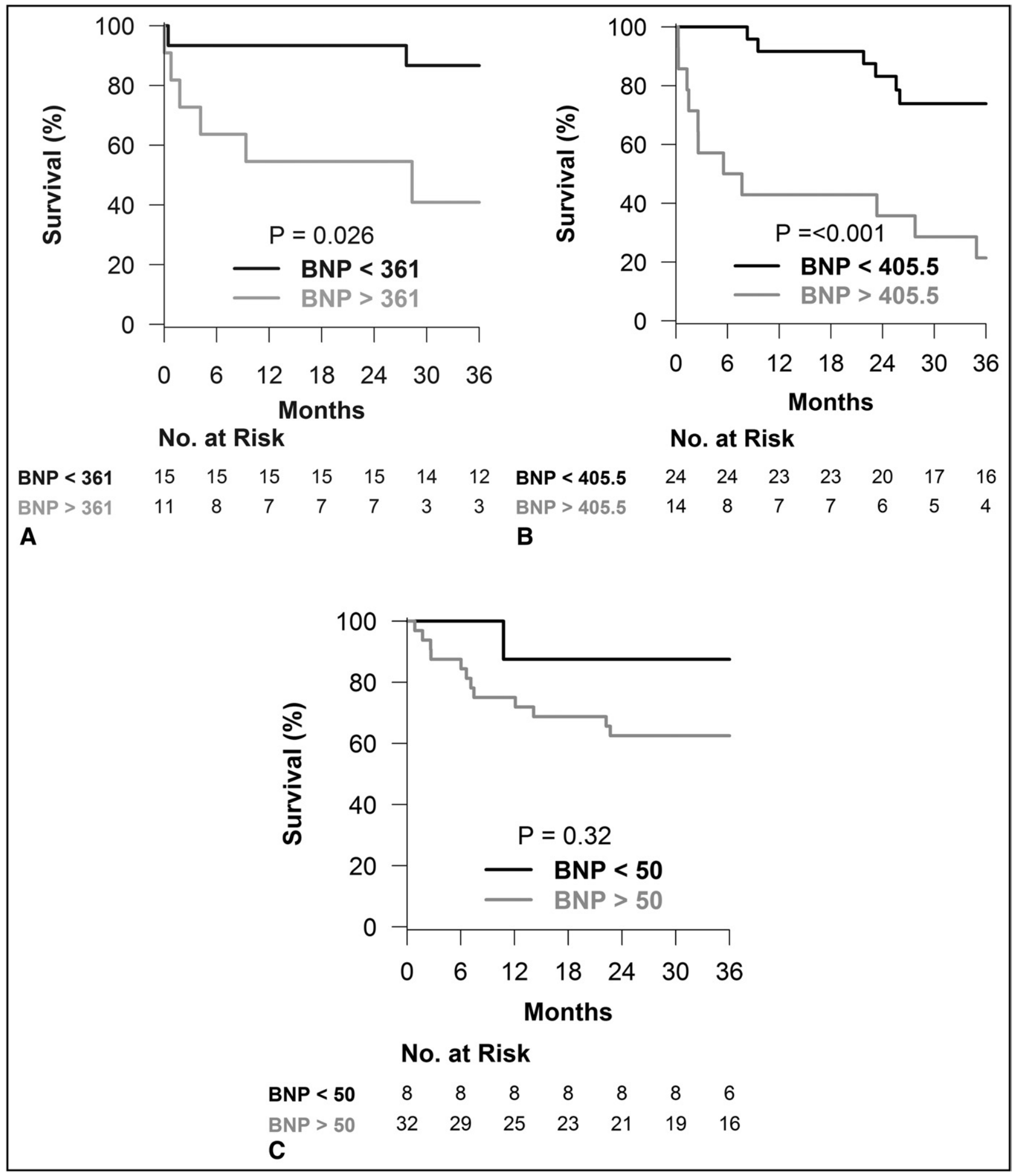

Figure 4. Kaplan-Meier curves for BNP as a function of BMI category: $(A)$ lean, $(B)$ overweight, and $(C)$ obese.

and N-terminal pro-BNP have been shown to increase with significant weight loss after bariatric surgery. ${ }^{20}$

Our study had limitations. The BMI was generally determined at right-sided heart catheterization and the BNP, functional status, and echocardiographic data were obtained within 2 months of heart catheterization. Our sample sizes within each BMI group were small; thus, BNP associations with NYHA functional class and hemodynamics could not be reliably performed because of the lack of statistical power. An increased BMI can result 


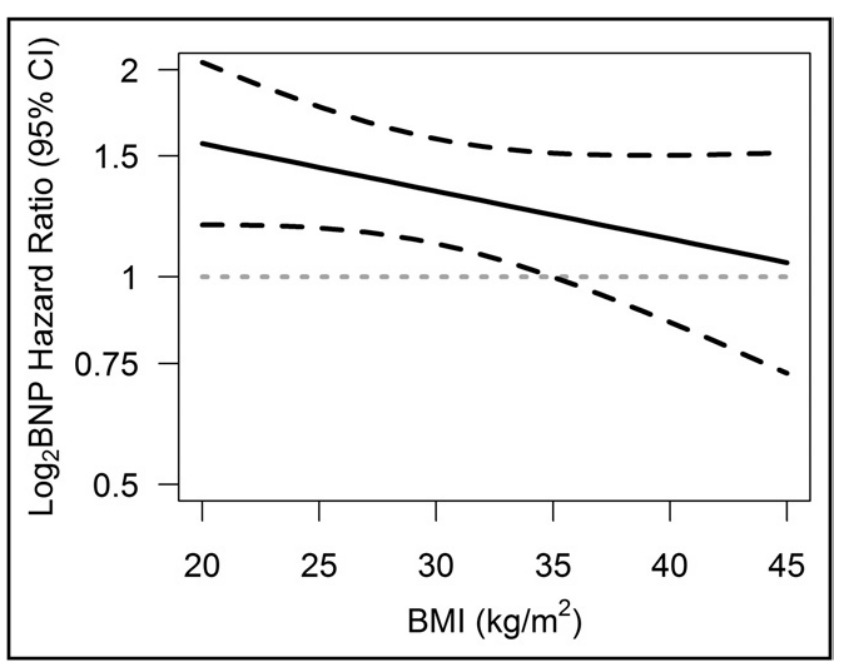

Figure 5. Significance of association of BNP and survival as a function of BMI demonstrating a gradual weakening of the hazard ratio for survival with respect to a doubling in BNP (obtained using $\log 2 \mathrm{BNP}$ as a Cox model predictor). The point at which the $95 \%$ confidence intervals begin to contain the value 1.0 is a BMI of $35 \mathrm{~kg} / \mathrm{m}^{2}$.

not only from increased adipose tissue, but could also indicate fluid retention from ascites, peripheral edema, and progressive right-sided heart failure. Consequently, the measures of fat mass or percentage of body fat would have been more desirable and should certainly be a component of any future prospective study. Fluid retention could have contributed to the BNP levels not being significantly different between the lean and overweight groups and the trend toward being greater in the overweight group. Nevertheless, obese patients in the present study had the lowest BNP levels despite similar or more severe disease compared to the lean or overweight patients. Finally, some variables in our database had missing data, although it was prospectively constructed.

1. Nagaya N, Nishikimi T, Uematsu M, Satoh T, Kyotani S, Sakamaki F, Kakishita M, Fukushima K, Okano Y, Nakanishi N, Miyatake K, Kangawa K. Plasma brain natriuretic peptide as a prognostic indicator in patients with primary pulmonary hypertension. Circulation 2000;102:865-870.

2. Leuchte HH, Holzapfel M, Baumgartner RA, Ding I, Neurohr C, Vogeser M, Kolbe T, Schwaiblmair M, Behr J. Clinical significance of brain natriuretic peptide in primary pulmonary hypertension. $J \mathrm{Am}$ Coll Cardiol 2004;43:764-770.

3. Nagaya N, Nishikimi T, Okano Y, Uematsu M, Satoh T, Kyotani S, Kuribayashi S, Hamada S, Kakishita M, Nakanishi N, Takamiya M, Kunieda T, Matsuo H, Kangawa K. Plasma brain natriuretic peptide levels increase in proportion to the extent of right ventricular dysfunction in pulmonary hypertension. J Am Coll Cardiol 1998;31:202-208.

4. Hoeper MM, Oudiz RJ, Peacock A, Tapson VF, Haworth SG, Frost AE, Torbicki A. End points and clinical trial designs in pulmonary arterial hypertension: clinical and regulatory perspectives. J Am Coll Cardiol 2004;43:48-55.

5. McLaughlin VV, Archer SL, Badesch DB, Barst RJ, Farber HW, Lindner JR, Mathier MA, McGoon MD, Park MH, Rosenson RS, Rubin LJ, Tapson VF, Varga J, Harrington RA, Anderson JL, Bates ER, Bridges CR, Eisenberg MJ, Ferrari VA, Grines CL, Hlatky MA, Jacobs AK, Kaul S, Lichtenberg RC, Lindner JR, Moliterno DJ, Mukherjee D, Pohost GM, Rosenson RS, Schofield RS, Shubrooks SJ, Stein JH, Tracy CM, Weitz HH, Wesley DJ. ACCF/AHA, ACCF, AHA 2009 expert consensus document on pulmonary hypertension: a report of the American College of Cardiology Foundation Task Force on Expert Consensus Documents and the American Heart Association: developed in collaboration with the American College of Chest Physicians, American Thoracic Society, and the Pulmonary Hypertension Association. Circulation 2009;119:2250-2294.

6. Badesch DB, Champion HC, Sanchez MA, Hoeper MM, Loyd JE, Manes A, McGoon M, Naeije R, Olschewski H, Oudiz RJ, Torbicki A. Diagnosis and assessment of pulmonary arterial hypertension. $\mathrm{J} \mathrm{Am}$ Coll Cardiol 2009;54:55-66.

7. Daniels LB, Maisel AS. Natriuretic peptides. J Am Coll Cardiol 2007;50:2357-2368.

8. Mehra MR, Uber PA, Park MH, Scott RL, Ventura HO, Harris BC, Frohlich ED. Obesity and suppressed B-type natriuretic peptide levels in heart failure. J Am Coll Cardiol 2004;43:1590-1595.

9. Taylor JA, Christenson RH, Rao K, Jorge M, Gottlieb SS. B-type natriuretic peptide and $\mathrm{N}$-terminal pro B-type natriuretic peptide are depressed in obesity despite higher left ventricular end diastolic pressures. Am Heart J 2006;152:1071-1076.

10. Horwich TB, Hamilton MA, Fonarow GC. B-type natriuretic peptide levels in obese patients with advanced heart failure. $\mathrm{J} \mathrm{Am} \mathrm{Coll} \mathrm{Cardiol}$ 2006; $47: 85-90$

11. Hunt SA, Abraham WT, Chin MH, et al. ACC/AHA 2005 guideline update for the diagnosis and management of chronic heart failure in the adult: a report of the American College of Cardiology/American Heart Association Task Force on Practice Guidelines (Writing Committee to update the 2001 guidelines for the evaluation and management of heart failure): developed in collaboration with the American College of Chest Physicians and the International Society for Heart and Lung Transplantation: endorsed by the Heart Rhythm Society. Circulation 2005;112: e154-e235.

12. Simonneau G, Robbins IM, Beghetti M, Channick RN, Delcroix M, Denton CP, Elliott CG, Gaine SP, Gladwin MT, Jing ZC, Krowka MJ, Langleben D, Nakanishi N, Souza R. Updated clinical classification of pulmonary hypertension. J Am Coll Cardiol 2009;54:43-54.

13. Gibbons RJ, Abrams J, Chatterjee K, Daley J, Deedwania PC, Douglas JS, Ferguson TB Jr, Fihn SD, Fraker TD Jr, Gardin JM, O’Rourke RA, Pasternak RC, Williams SV, Gibbons RJ, Alpert JS, Antman EM, Hiratzka LF, Fuster V, Faxon DP, Gregoratos G, Jacobs AK, Smith SC Jr, Gibbons RJ, Abrams J, Chatterjee K, Daley J, Deedwania PC, Douglas JS, Ferguson TB Jr, Fihn SD, Fraker TD Jr, Gardin JM, O'Rourke RA, Pasternak RC, Williams SV, Gibbons RJ, Alpert JS, Antman EM, Hiratzka LF, Fuster V, Faxon DP, Gregoratos G, Jacobs AK. ACC/AHA 2002 guideline update for the management of patients with chronic stable angina-summary article: a report of the American College of Cardiology/American Heart Association Task Force on Practice Guidelines (Committee on the Management of Patients With Chronic Stable Angina). Circulation 2003;107:149-158.

14. National Heart, Lung, and Blood Institute Expert Panel. Clinical Guidelines on the identification, evaluation, and treatment of overweight and obesity in adults: evidence report. Bethesda, Maryland: National Heart, Lung, and Blood Institute; 1998. Available at: http://www.nhlbi.nih.gov/ guidelines/obesity/ob_home.htm. Accessed July 2010.

15. Wang TJ, Larson MG, Levy D, Leip EP, Benjamin EJ, Wilson PWF, Sutherland P, Omland T, Vasan RS. Impact of age and sex on plasma natriuretic peptide levels in healthy adults. Am J Cardiol 2002;90:254-258.

16. Wang TJ, Larson MG, Levy D, Benjamin EJ, Leip EP, Wilson PW, Vasan RS. Impact of obesity on plasma natriuretic peptide levels. Circulation 2004;109:594-600.

17. Sarzani R, Dessi-Fulgheri P, Paci VM, Espinosa E, Rappelli A. How obesity affects the cut-points for B-type natriuretic peptide in the diagnosis of acute heart failure: results from the breathing not properly multinational study: expression of natriuretic peptide receptors in human adipose and other tissues. J Endocrinol Invest 1996;19:581-585.

18. Dessi-Fulgheri P, Sarzani R, Rappelli A. The natriuretic peptide system in obesity-related hypertension: new pathophysiological aspects. J Nephrol 1998;11:296-299.

19. Das SR, Drazner MH, Dries DL, Vega GL, Stanek HG, Abdullah SM, Canham RM, Chung AK, Leonard D, Wians FH Jr, de Lemos JA. Impact of body mass and body composition on circulating levels of natriuretic peptides: results from the Dallas heart study. Circulation 2005;112:2163-2168.

20. van Kimmenade R, van Dielen F, Bakker J, Nijhuis J, Crijns H, Buurman W, van Dieijen-Visser M, Greve JW, Pinto Y. Is brain natriuretic peptide production decreased in obese subjects? J Am Coll Cardiol 2006;47:886-887. 